\title{
Importance of Enhanced Mass Resolution in Removing Interferences When Measuring Volatile Organic Compounds in Human Blood By Using Purge-and-Trap Gas Chromatography/Mass Spectrometry
}

\author{
Michael A. Bonin, David L. Ashley, Fred L. Cardinali, Joan M. McCraw, \\ and Donald G. Patterson, Jr. \\ Division of Environmental Health Laboratory Sciences, National Center for Environmental Health and Injury \\ Control, Centers for Disease Control, Public Health Service, U.S. Department of Health and Human Services, \\ Atlanta, Georgia, USA
}

The number of volatile organic compounds (VOCs) that can be purged from human blood is so great that they cannot be separated completely by capillary gas chromatography. As a result, the single-mass chromatograms used for quantitating the target compounds by mass spectrometry have many interferences at nominal (integer) mass resolution of a quadrupole mass spectrometer. The results of these interferences range from small errors in quantitation to completely erroneous results for the target VOCs. By using a magnetic sector mass spectrometer, these interferences at nominal mass can be removed at higher resolution by lowering the ion chromatogram windows around the masses of interest. At 3000 resolution (10\% valley definition), unique single-ion chromatograms can be made for the quantitation ions of the target VOCs. Full-scan mass data are required to allow the identification of unknown compounds purged from the blood. By using isotope-dilution mass spectrometry, most target VOCs can be detected in the low parts per trillion range for a 10-mL quantity of blood from which the VOCs have been removed by a purge-and-trap method. (] Am Soc Mass Spectrom 1992, 3, 831-841)

$\mathrm{T}$ The exposure of people today to the volatile organic compounds (VOCs) present in the environment is of great concern in the public health field $[1,2]$. The role of drinking water as a source of VOCs has been studied in recent years [3-7] as have the presence and sources of VOCS in indoor air [8-11]. Although the average body burden of VOCs in the general population is uncertain, it must be determined if researchers are to construct a baseline for accessing the occurrence and degree of exposure to VOCs. Many researchers have measured the body burden of VOCs by VOC levels in breath [12-14]. Huwever, results of comparative studies of breath and blood as the medium for body burden measurements for VOCs indicate that blood should yield more reliable values [15-17]. Several studies of VOCs in human blood have been reported in which a purge-and-trap analysis was used together with a gas chromatograph and a quadrupole mass spectrometer $[18,19]$. Generally investigators

Address reprint requests to Michael A. Bonin, Centers for Disease control, F 17, 1600 Clifton Road, Atlanta, GA 30333. using these methods have reported detection limits in blood in the parts per billion ( $\mathrm{ppb}$ ) to high parts per trillion (ppt) range, which is not sensitive enough to assess the body burden of many VOCs among unexposed persons in the general population.

Human blood was chosen as the analytic medium for the measurement of VOC levels in a reference population, which is part of the current Third National Health and Nutrition Examination Survey (NHANES III). The NHANES III survey is the first national study to measure levels of VOCs in the population. Previously, blood had been used in the earlier national surveys (NHANES I and NHANES II) to measure levels of metabolic elements and vitamins and also in NHANES II to measure the levels of pesticide residues [20-22]. Our choices of analytical procedures were circumscribed by the fact that the protocol of the NHANES III study would provide only one $10-\mathrm{mL}$ sample of blood for each subject for the measurement of VOCs. The NHANES III protocol required us to determine the blood levels of the metabolic products acetone, carbon disulfide, and 2-butanone as well as a 
number of volatile priority pollutants for each sample. For this study we needed a method with a large dynamic range that could yield low parts per trillion detection limits for the VOCs such as chloroform and methylene chloride and handle the high levels of metabolic products such as acetone, which is present commonly at low parts per million levels. Also the NHANES III protocol required each sample to be searched for nontarget compounds that might prove to be of interest in the future. For NHANES III, we developed a method for measuring more than 30 VOCs in a 10-mL sample of human blood by combining purge-and-trap isolation and concentration of the VOCs with capillary gas chromatography and medium resolution magnetic sector mass spectrometry, using an isotope dilution method. Because the identification of unknown compounds was required for this study, full scan mass data were used instead of a selected-ionmonitoring method to give us the maximum amount of information for each sample. The problem of coeluting compounds with ions having the same nominal mass was solved by using a magnetic sector mass spectrometer with its higher mass resolution instead of a quadrupole mass spectrometer that could yield only nominal (integer) mass resolution. We achieved a balance of high sensitivity versus mass discrimination by operating the mass spectrometer at 3000 resolution (10\% valley definition). Most target VOCs could be detected by our method in the low parts per trillion range for a $10-\mathrm{mL}$ sample of whole blood.

\section{Experimental}

\section{Instrumental Analysis}

The analytic system developed for the VOC analysis consists of a purge-and-trap system interfaced to a gas chromatograph with a capillary chromatography column connected directly to the ion source of a magnetic sector mass spectrometer.

The purge-and-trap system made by Tekmar Cu. (Cincinnati, $\mathrm{OH}$ ) consists of a LSC 2000 purge-and-trap concentrator coupled to an ALS 2016 automatic sampler, an automatic sample heating unit, and a capillary interface that allows on-column cryofocusing. A heated, fused silica transfer line from the LSC 2000 unit was connected directly to the capillary chromatography column by a gold-plated union above the cryofocus zone inside the capillary interface. Research-grade helium was used for both purge gas and gas chromatography carrier gas. A flow meter was attached to the vent port of the LSC 2000 unit to monitor the purge flow rate, because the rate was found to vary by as much as $10 \mathrm{~mL} / \mathrm{min}$ among the sparger ports for the same setting of the flow needle valve. Purge flow rate was maintained at $30 \mathrm{~mL} / \mathrm{min}$ at $20 \mathrm{psi}$, which was essential to prevent trap breakthrough. Glass-lined tubing and fused silica transfer lines were used for all sample paths for inertness. The internal valves, metal unions, and transfer lines were heated at $100{ }^{\circ} \mathrm{C}$. The
25-mL glass tube needle spargers used for samples were heated by individual heating jackets. Each run began with a $3-\mathrm{min}$ heating cycle at $30^{\circ} \mathrm{C}$ to ensure uniformity. The samples were then purged with helium for $15 \mathrm{~min}$ at $30^{\circ} \mathrm{C}$, during which time the VOCs were trapped on a Tenax trap (Tenax packed in a 0.125 in $\times 12$ in stainless steel tube from Tekmar $\mathrm{Co}$.). This trap was then dry purged with helium for $6 \mathrm{~min}$. The VOCs were desorbed by heating the trap at $180^{\circ} \mathrm{C}$ for 4 min and then trapped and refocused at the head of a capillary chromatography column by cryogenic cooling at $-150{ }^{\circ} \mathrm{C}$ with liquid nitrogen. The cold-trapped VOCs were vaporized by being heated at $200{ }^{\circ} \mathrm{C}$ for $0.75 \mathrm{~min}$. Finally the trap was baked at $225^{\circ} \mathrm{C}$ for 36 $\min$.

Chromatography was performed with a HewlettPackard (Avondale, PA) 5890 gas chromatograph (GC) with subambient liquid nitrogen valve. The column was a DB-624 (J \& W Scientific, Folsom, CA) $30 \mathrm{~m} \times$ $0.32 \mathrm{~mm}$, with a $1.8-\mu \mathrm{m}$ film thickness. The carrier gas was helium at 5 -psi head pressure and $1-\mathrm{mL} / \mathrm{min}$ flow. The column was run directly from the union in the Tekmar capillary interface through the injection heater (heated at $200{ }^{\circ} \mathrm{C}$ ) and the oven of the $G C$ to the ion source block of the mass spectrometer. A heated interface controlled by the mass spectrometer at about $200{ }^{\circ} \mathrm{C}$ joined the $\mathrm{GC}$ oven with the mass spectrometer. The GC temperature program consisted of the following sequence: initial hold at $0{ }^{\circ} \mathrm{C}$ for $1.5 \mathrm{~min}$, ramp at $12{ }^{\circ} \mathrm{C} / \mathrm{min}$ for $2.5 \mathrm{~min}$, hold at $30^{\circ} \mathrm{C}$ for $2 \mathrm{~min}$, ramp at $8{ }^{\circ} \mathrm{C} / \mathrm{min}$ for $20 \mathrm{~min}$, and hold at $190^{\circ} \mathrm{C}$ for $10 \mathrm{~min}$. Total run time from helium purging to the retum to initial conditions was about $70 \mathrm{~min}$.

Compound identification was made with full-scan data from a VG 7070E (VG Analytical Ltd., Manchester, UK) double-focusing magnetic sector mass spectrometer by electron ionization at an electron energy of $70 \mathrm{eV}$. The mass spectrometer was scanned exponentially from 190 down to $34 \mathrm{Da}$ in the current mode at $1 \mathrm{sec} /$ decade and with a magnet settling time of $0.20 \mathrm{sec}$, which gave a scan cycle time of $0.92 \mathrm{sec}$. The instrument functions and data collection were controlled by a VG 11-250J data system consisting of a Digital PDP11/73 computer with a DEC RD53 disk drive and a DEC TK50 tape system (Digital Equipment Corp., Maynard, MA).

The mass spectrometer was tuned and calibrated with perfluorokerosene (PFK) at 3000 resolution (10\% valley definition) before each run, and then the PFK was pumped away. The removal of the PFK was necessary because its ions of $m / z 99.9936$ and 111.9936 could not be separated at 3000 resolution from the quantitation ions of some VOCs such as [ $\left.{ }^{2} \mathrm{H}_{3}\right]-1,1,1$-trichloroethane and chlorobenzene. The VG calibration program was used to generate a calibration file from the PFK run by using three lockmasses $(m / z \quad 168.9888$, 130.9920, and 118.9920) and a primary reference file of PFK. For each scanning acquisition, the mass-peak times were stored and an empty subfile was created for mass data so that afterwards the experimental 
calibration file could be used with a VG mass measurement program to calculate accurate masses for the run. After each run, the stability and accuracy of the mass scale were checked by calculating the accurate masses for a set of compounds spanning both ranges in mass and elution time: $\left[{ }^{13} \mathrm{C}\right]$ chloroform, $\left[{ }^{13} \mathrm{C}_{6}\right]$ benzene, $\left[{ }^{2} \mathrm{H}_{10}\right]$ ethylbenzene, $\left[{ }^{13} \mathrm{C}\right]$ bromoform, and naphthalene (Table 1). The data for a typical blood sample of the NHANES III study (a 9.59-g sample of blood spiked with internal standard solution), given in Table 1 , show that the mass scale is reasonably stable over the time scale of each GC peak and over the duration of the analytical run. To be acceptable, the absolute value of maximum deviation from theoretical mass should be less than $0.025 \mathrm{Da}$ in all cases. Usually the deviation was much less even though there was a half-hour delay between the PFK calibration and the start of data acquisition. The mass scale stability was sufficiently good to allow the automated generation of mass chromatograms from the theoretical masses with a mass window of 0.03 Da over the entire GC run. The signalto-noise ratios for this sample of blood are typical of the usual run (analyte (quantitation ion, concentration, $5 / \mathrm{N}$ ratiol): $\left[{ }^{13} \mathrm{C}\right]$ chloroform $\left({ }^{13} \mathrm{CHCl}_{2}^{+}, 80 \mathrm{ppt}, 30 / 1\right)$, $\left[{ }^{13} \mathrm{C}_{6}\right]$ benzene $\left({ }^{13} \mathrm{C}_{6} \mathrm{H}_{6}^{+} ; 180 \mathrm{ppt}, 100 / 1\right),\left[{ }^{2} \mathrm{H}_{10}\right]$ ethylbenzene $\left(\mathrm{C}_{8}^{2} \mathrm{H}_{10}^{+}, 350 \mathrm{ppt}, 100 / 1\right)$, and $\left[{ }^{13} \mathrm{C}\right]$ brumofurm $\left({ }^{13} \mathrm{CH}^{79} \mathrm{Br}^{81} \mathrm{Br}^{+}, 500 \mathrm{ppt}, 30 / 1\right)$.

The necessity of using higher mass resolution for the blood samples dictated the choice of a magnetic sector mass spectrometer over a quadrupole mass spectrometer with its nominal (unit) mass resolution. A resolution of $\mathbf{3 0 0 0}$ was chosen for the full-scan data to achieve the greatest mass discrimination consistent with a sensitivity in the low parts per trillion range for most of the target VOCs. A resolution of 3000 was the best compromise under our experimental constraints of one $10-\mathrm{mL}$ sample of blood per individual and the need to use full-scan data. For full-scan spectra at 3000 resolution, signal-to-noise ratios of $3 / 1$ to $5 / 1$ were achievable at the detection limits of many target VOCs for a $10-\mathrm{mL}$ blood sample with our VG 7070E mass spectrometer. Because we had to use full-scan data, an increase of mass resolution above 3000 caused an unacceptable decrease in signal intensity. Because we must be able to handle any nontarget compounds that might be present in the blood samples, we need to be able to form unique mass chromatograms for the greater majority of possible volatile compounds. The ability to form unique mass chromatograms for acetonitrile and 2-propanol, which form a merged GC peak in many blood samples, was judged to be consistent with the required mass discrimination. The molecular ion $\mathrm{C}_{2} \mathrm{H}_{3} \mathrm{~N}^{+\cdot}(m / z$ 41.0265) of acetonitrile is just separable from the $\mathrm{C}_{3} \mathrm{H}_{5}^{+}$ion $(\mathrm{m} / z$ 41.0391) of 2propanol at 3000 resolution.

Full-scan data were needed for this study because of the requirement to search for and identify all nontarget compounds that might be purged from the blood samples, some of which compounds might possibly be found to be harmful in the future. A full-scan mass spectral library of target VOCs and their labeled analogs was created from standards run under our experimental conditions. The positive identification of a target VOC or labeled analog was based on a match of its full-scan mass spectrum with the corresponding full-scan mass spectrum of a standard in our user library. The minimum requirement for compound detection was that the quantitation ion and one additional major ion of the compound must be present in at least two consecutive scans in its retention time window and qualitatively have a similar intensity ratio to that found in the standard mass spectrum in our user library. The retention time window of each target VOC is a five-scan interval determined relative to its own labeled analog.

The method validation and data processing for the antalysis of the VOCs are discussed elsewhere [23].

\section{Sample Preparation}

Human blood samples were collected as part of the Third National Health and Nutrition Examination Survey. The blood was drawn in $10-\mathrm{mL}$ portions by GreyTop vacutainers containing solid potassium oxalate and sodium fluoride (Becton Dickinson, Rutherford, NJ), which were specially processed in our laboratory to remove VOC contamination resulting mainly from the rubber stopper. The vacutainers were disassembled and the glass tubes and rubber stoppers were heated for 2 weeks at $70{ }^{\circ} \mathrm{C}$, under vacuum. After being

Table 1. Typical mass scale stability over the duration of GC-MS run for a blood sample ${ }^{a}$

\begin{tabular}{|c|c|c|c|c|}
\hline Analyte & $\begin{array}{c}\text { Retention } \\
\text { time } \\
\text { \{minl }\end{array}$ & $\begin{array}{l}\text { Scans } \\
\text { in peak }\end{array}$ & $\begin{array}{c}\text { Experimental } \\
\text { mean mass } \pm \text { S.D. }\end{array}$ & $\begin{array}{l}\text { Deviation from } \\
\text { theoretical mass }\end{array}$ \\
\hline [ ${ }^{13}$ ClChloroform & 9.07 & $\overline{77}$ & $83.9404 \pm 0.0013$ & $-0.0085 \pm 0.0013$ \\
\hline$I^{13} C_{6}$ JBenzene & 9.93 & 9 & $84.0594 \pm 0.0017$ & $-0.0077 \pm 0.0017$ \\
\hline $\left.\mathrm{I}^{2} \mathrm{H}_{10}\right]$ Ethylbenzene & 15.93 & 9 & $116.1325 \pm 0.0030$ & $-0.0085 \pm 0.0030$ \\
\hline I $^{13}$ ClBromoform & 17.20 & 7 & $173.8355 \pm 0.0014$ & $-0.0103 \pm 0.0014$ \\
\hline Naphthalene & 24.28 & 9 & $128.0538 \pm 0.0016$ & $-0.0088 \pm 0.0016$ \\
\hline
\end{tabular}

a The experimental data are for a $9.59-\mathrm{g}$ sample of whole human blood spiked with interial standard solution. Single-mass chromatograms from this sample of blood are shown in Figures 1,2 , and 3 .

The theoretical masses are the following: $\left[{ }^{73} \mathrm{C}\right]$ chloroform, 83.9489: $\left[{ }^{13} \mathrm{C}_{6}\right]$ lbenzene. 84.0671: $I^{2} \mathrm{H}_{10}$ ]ethylbenzene, 116.1410; $\left[{ }^{13}\right.$ C]bromoform, 173.8458; naphthalene, 128.0626. 
reassembled, the vacutainers were evacuated and then sterilized using a cobalt 60 gamma ray source. The blood was cooled and shipped refrigerated to this laboratory and then stored at $4{ }^{\circ} \mathrm{C}$. Before analysis, the blood was removed from refrigeration and gently remixed by a hematology mixer. The blood was withdrawn from the vacutainers by piercing the septum with a disposable 1-inch 18 gauge stainless steel needle attached to a glass Hamilton $10-\mathrm{mL}$ gas-tight syringe with a Luer tip. After the needle was removed, $20 \mu \mathrm{L}$ of internal standard solution in methanol was added directly to the blood in the syringe by an SMI Micro/Pettor (American Hospital Supply Corp., Miami, FL) with a disposable glass capillary tube; this procedure was used for all types of samples. After the syringe was attached to a sparger valve on the purgeand-trap system, the blood was injected into a glass tube sparger, containing small chips of solid antifoam B. The solid antifoam B was prepared in this laboratory from an aqueous emulsion of antifoam B (Sigma Chemical Co., St. Louis, MO) by room temperature evaporation at atmospheric pressure.

Human serum was used for quality control in this study. The serum had to be purged overnight with research-grade helium to produce a virtually volatilefree material. Two batches of serum were prepared at two spiking levels of native analytes and then stored in the dark at $-60^{\circ} \mathrm{C}$ in 10 -mL portions in glass serum bottles (Wheaton Scientific, Millville, NJ) with Teflon-faced septa. Each day, a serum quality control sample was removed and allowed to thaw at room temperature.

Standard native compounds were purchased from Aldrich Chemical Co. (Milwaukee, WI) or Burdick and Jackson (Muskegon, MI). Isotopically labeled analogs were purchased as neat compounds from Cambridge Isotope Laboratories, Inc. (Woburn, MA) or from Merck, Sharp, and Dohme/Isotopes (St. Louis, MO). Stock solutions were prepared in methanol (purge and trap grade from Burdick and Jackson) and were transferred to and sealed in small glass ampoules, which were then stored in the dark at $-60{ }^{\circ} \mathrm{C}$. The internal standard solution in methanol and a water standard of native analytes in "VOC-free" water were prepared fresh each day. Samples of "VOC-free" water (containing $<20$ ppt of most VOCs) were prepared by helium purging of rural well water at elevated temperature followed by distillation under helium purge, using a similar method to that reported previously [24].

\section{Results and Discussion}

\section{Chromatography and Isotope-Dilution Mass Spectrometry}

Isotope-dilution mass spectrometry was used here to quantitate volatile organics from biological media according to previously described methods [25]. The recovery of a VOC from whole blood by helium purg- ing techniques depends on its interactions with the various components of the blood matrix such as lipids, proteins, water, salts, and blood cells. Ihese matrix interactions tend to be highly specific for different compounds. To minimize the matrix effects on analyte recovery, it is essential to use an isotopically labeled analog of an analyte as the internal standard because the labeled analog should closely mimic the behavior of the analyte in the blood. As one pushes the detection limits for VOCs in blood to the low parts per trillion level, the use of isotopically labeled analogs becomes critical to quantitative accuracy.

The 35 VOCs that were measured in blood were referenced against 33 labeled internal standards. Only two VOCs have no labeled analog as an internal standard. The 1,3-dichlorobenzene is referenced against $\left[{ }^{2} \mathrm{H}_{4}\right]-1,4$-dichlorobenzene. On the DB-624 column, $m$ xylene and $p$-xylene coelute and are reported as a composite amount, which is referenced against $\left[{ }^{2} \mathrm{H}_{10}\right]-$ $p$-xylene. The relative retention times for the analytes and internal standards calculated against $\left[{ }^{2} \mathrm{H}_{8}\right]$ toluene are given in Table 2 for the DB-624 column under our experimental conditions. The retention times were used to establish the set of retention time windows used for automatic area determination of the mass chromatograms used for quantitative analysis. The accurate masses and chemical formulae of the quantitation ions for these compounds are listed in Table 3 . Because we are using full-scan data, we generate a single-ion chromatogram by using the theoretical mass of the quantitation ion with a limited mass window of 0.03 $\mathrm{Da}$ from the full-scan data. These single-ion chromatograms are used for quantitation. For $\left[{ }^{2} \mathrm{H}_{4}\right]-1,2-$ dichloroethane, dibromochloromethane, and $\left[{ }^{13} \mathrm{C}\right] \mathrm{di}-$ bromochloromethane, the "quantitation ion" at 3000 mass resolution is a pair of unresolved ions, respectively: $\mathrm{C}_{2}^{3 / 7} \mathrm{Cl}^{2} \mathrm{H}_{3}^{++}(m / z 67,0082)$ and $\mathrm{C}_{2}^{35} \mathrm{Cl}^{2} \mathrm{H}_{4}^{+}(\mathrm{m} / z$ 67.0256); $\mathrm{CH}^{37} \mathrm{Cl}^{79} \mathrm{Br}^{+}(m / z \quad 128.8921)$ and $\mathrm{CH}^{35} \mathrm{Cl}^{81} \mathrm{Br}^{+} \quad(m / z \quad 128.8930) ;{ }^{13} \mathrm{CH}^{37} \mathrm{Cl}^{79} \mathrm{Br}^{+}(m / z$ 129.8954) and ${ }^{13} \mathrm{CH}^{35} \mathrm{Cl}^{81} \mathrm{Br}^{+}(m / z$ 129.8963). For each pair of iuns, an intermediate mass is used with the limited mass window to construct a specific mass. chromatogram that includes the mass signals for both of the unresolved ions. The quantitation ions are only used in the quantitative procedure; compound identification depends on the full-scan mass spectral match of the compound with a corresponding mass spectrum of a standard in our user library.

The choices of quantitation ions for the metabolic products acetone, carbon disulfide, and 2-butanone were dictated by their high concentrations in the blood, which usually range from the high parts per billion level to the low parts per million level. For acetone both the base peak $\mathrm{C}_{2} \mathrm{H}_{3} \mathrm{O}^{+}(m / z$ 43.0189) and the molecular ion $\mathrm{C}_{3} \mathrm{H}_{6} \mathrm{O}^{+-}(\mathrm{m} / z$ 58.0419) are saturated signals at the gain and voltage levels of the mass spectrometer that are required to achieve low parts per trillion detection levels in the blood for the priority pollutants such as chloroform and methylene chloride. 
Table 2. Relative GC retention times (relative to $\left[{ }^{2} \mathrm{H}_{8}\right]$ toluene) on DB-624 capillary column for target VOCs and their labeled internal standards

\begin{tabular}{|c|c|c|c|}
\hline Target VOCs (natives) & $\begin{array}{l}\text { Relative retention } \\
\text { time }\end{array}$ & $\begin{array}{l}\text { Internal standard } \\
R=\text { native }\end{array}$ & $\begin{array}{l}\text { Relative retention } \\
\text { time }\end{array}$ \\
\hline 1,1-Dichloroethene & 0.367 & $\overline{\left[{ }^{2} \mathrm{H}_{2}\right] \mathrm{R}}$ & 0.366 \\
\hline Acetone & 0.383 & {$\left[{ }^{13} \mathrm{C}_{3}\right] \mathrm{R}$} & 0.384 \\
\hline Carbon disulfide & 0.387 & {$\left[{ }^{43} \mathrm{C}\right] \mathrm{R}$} & 0.386 \\
\hline Bromoethane & 0.390 & {$\left[{ }^{13} \mathrm{C}\right] \mathrm{R}$} & 0.390 \\
\hline Methylene chloride & 0.446 & {$\left[{ }^{13} \mathrm{C}\right] \mathrm{R}$} & 0.446 \\
\hline trans-1,2-Dichloroethene & 0.488 & {$\left[{ }^{2} \mathrm{H}_{2}\right] R$} & 0.486 \\
\hline hexane & 0.538 & {$\left[{ }^{2} \mathrm{H}_{14}\right] R$} & 0.515 \\
\hline 1,1-Dichloroethane & 0.551 & {$\left[{ }^{2} \mathbf{H}_{3}\right] R$} & 0.546 \\
\hline cis-1,2-Dichloroethene & 0.635 & {$\left[{ }^{2} \mathrm{H}_{2}\right] \mathrm{R}$} & 0.632 \\
\hline 2-Butanone & 0.642 & {$\left[4-{ }^{2} \mathrm{H}_{3}\right] \mathrm{R}$} & 0.637 \\
\hline Chloroform & 0.684 & {$\left[{ }^{13} \mathrm{C}\right] \mathrm{R}$} & 0.684 \\
\hline 1,1,1-Trichioroethane & 0.702 & {$\left[{ }^{2} \mathrm{H}_{3}\right] \mathrm{R}$} & 0.695 \\
\hline Carbon tetrachloride & 0.724 & {$\left[{ }^{13} \mathrm{C}\right] \mathrm{R}$} & 0.724 \\
\hline Benzene & 0.751 & {$\left[{ }^{13} \mathrm{C}_{6}\right] \mathrm{R}$} & 0.751 \\
\hline 1,2-Dichloroethane & 0.754 & {$\left[{ }^{2} \mathrm{H}_{4}\right] R$} & 0.745 \\
\hline Trichloroethene & 0.840 & {$\left[{ }^{13} \mathrm{C}\right] \mathrm{R}$} & 0.840 \\
\hline 1,2-Dichloropropane & 0.866 & {$\left[{ }^{2} H_{6}\right] R$} & 0.855 \\
\hline Dibromomethane & 0.881 & {$\left[{ }^{2} \mathrm{H}_{2}\right] \mathrm{R}$} & 0.877 \\
\hline Bromadichloromethane & 0.906 & {$\left[^{13} \mathrm{ClR}\right.$} & 0.906 \\
\hline Toluene & 1.009 & {$\left[{ }^{2} \mathrm{H}_{\mathrm{B}}\right] \mathrm{R}$} & 1.000 \\
\hline 1,1.2-Trichloroethane & 1.062 & {$\left[{ }^{2} \mathrm{H}_{3}\right] \mathrm{R}$} & 1.057 \\
\hline Tetrachloroethene & 1.082 & {$\left[{ }^{13} \mathrm{ClR}\right.$} & 1.081 \\
\hline Dibromochloromethane & 1.113 & {$\left[{ }^{13} \mathrm{C}\right] \mathrm{R}$} & 1.113 \\
\hline Chlorobenzene & 1.195 & $\left.I^{2} H_{5}\right] R$ & 1.192 \\
\hline Ethylbenzene & 1.214 & {$\left[{ }^{2} \mathrm{H}_{10}\right] \mathrm{R}$} & 1.204 \\
\hline$m$-/p-Xylene & 1.231 & {$\left[{ }^{2} \mathrm{H}_{10}\right] p-\mathrm{R}$} & 1.220 \\
\hline$o-X y l e n e$ & 1.285 & {$\left[{ }^{13} \mathrm{C}_{2}\right] \mathrm{R}$} & 1.284 \\
\hline Styrene & 1.287 & {$\left[{ }^{2} \mathrm{H}_{8}\right] \mathrm{F}$} & 1.281 \\
\hline Bromoform & 1.307 & {$\left[{ }^{13} \mathrm{C}\right] R$} & 1.309 \\
\hline 1,1,2,2-Tetrachloroethane & 1.380 & {$\left[{ }^{2} \mathrm{H}_{2}\right] R$} & 1.378 \\
\hline 1,3-Dichlorabenzene & 1.512 & $\mathrm{~b}$ & \\
\hline 1,4-Dichlorobenzene & 1.525 & {$\left[{ }^{2} \mathrm{H}_{4}\right] \mathrm{R}$} & 1.523 \\
\hline 1,2-Dichlorobenzene & 1.577 & {$\left[{ }^{2} \mathrm{H}_{4}\right] \mathrm{R}$} & 1.575 \\
\hline Hexachloroethane & 1.615 & $\left.{ }^{13} \mathrm{C}\right] \mathrm{R}$ & 1.616 \\
\hline
\end{tabular}

\footnotetext{
a The everage retention time for $\left[{ }^{2} \mathrm{H}_{8}\right.$ ltoluene is $13.25 \pm 0.02 \mathrm{~min}$. The relative retention times calculated against $\left[{ }^{2} \mathrm{H}_{8}\right.$ ltoluene are average values for 12 runs of standard water solutions by using our purge-and-trap/GC method. The standard deviation of each relative retention time is 0.001 .

Internal standard for 1,3-dichlnrobenzene is $\left[{ }^{2} \mathrm{H}_{4}\right]-1,4$-dichlorobenzene.
}

The naturally occurring carbon- 13 species ${ }^{13} \mathrm{CC}_{2} \mathrm{H}_{6} \mathrm{O}^{+}$ $(m / z$ 59.0452) was chosen as the quantitation ion for acetone because its signal level usually ranged between 20 and $80 \%$ of the signal saturation level for the average blood sample. For similar reasons, a less-intense ion of the mass spectrum was chosen for the quantitation ion for both carbon disulfide $\left(\mathrm{CS}^{34} \mathrm{~S}^{+}\right.$; $m / z 77.9399)$ and 2-butanone $\left(\mathrm{C}_{4} \mathrm{H}_{8} \mathrm{O}^{+}, m / z\right.$ 72.0575). The choice of these less-intense ions is the best compromise available that allows us to measure simultaneously parts per trillion levels of VOCs and the much higher levels of metabolic products. The protocol of the NHANES III survey required us to measure these metabolic products.
The use of the medium mass resolution of 3000 presented us with mass interferences that we had to solve without recourse to even higher resolution. Quantitation ions for each native analyte and its labeled analog were chosen to minimize the contribution of the native analyte to the detection of the labeled analog and vice versa, if the chromatographic separation of the pair was incomplete. When a deuterated internal standard is used, one must often choose a less intense ion in order to minimize the interference between the native and labeled pair. One example is $\left[{ }^{2} \mathrm{H}_{2}\right]-1,1$-dichloroethene and 1,1-dichloroethene, which elute within 3 seconds of each other on the DB-624 column. At 3000 resolution their more intense common 
Table 3. The quantitation ions for target VOCs and their labeled internal standards listed in order of increasing GC retention time (see Table 2)

\begin{tabular}{|c|c|c|c|c|c|}
\hline \multirow[b]{2}{*}{ Target VOCs (natives) } & \multicolumn{2}{|c|}{ Quantitation ion } & \multirow{2}{*}{$\frac{\text { Internal standard }}{\mathbf{R}=\text { native }}$} & \multicolumn{2}{|c|}{ Quantitation ion } \\
\hline & $m / z$ & Formula ${ }^{\theta}$ & & $m / z$ & Formula \\
\hline 1,1-Dichloroethene & 95.9534 & $\mathrm{C}_{2} \mathrm{H}_{2} \mathrm{Cl}_{2}$ & {$\left[{ }^{2} \mathrm{H}_{2}\right] \mathrm{R}$} & 64.9941 & $\mathrm{C}_{2}{ }^{37} \mathrm{Cl}^{2} \mathrm{H}_{2}$ \\
\hline Acetone & 59.0452 & ${ }^{13} \mathrm{CC}_{2} \mathrm{H}_{6} \mathrm{O}$ & {$\left[{ }^{13} \mathrm{C}_{3}\right] \mathrm{R}$} & 61.0519 & ${ }^{13} \mathrm{C}_{3} \mathrm{H}_{6} \mathrm{O}$ \\
\hline Carbon disulfide & 77.9399 & $\operatorname{cs}^{34} s$ & {$\left[{ }^{13} \mathrm{C}\right] \mathrm{R}$} & 78.9433 & ${ }^{13} C^{34} S S$ \\
\hline Bromoethane & 107.9575 & $\mathrm{C}_{2} \mathrm{H}_{5}^{79} \mathrm{Br}$ & {$\left[{ }^{13} \mathrm{C}\right] \mathrm{R}$} & 110.9588 & ${ }^{13} \mathrm{CCH}_{5}^{81} \mathrm{Br}_{\mathrm{r}}$ \\
\hline Methylene chloride & 83.9534 & $\mathrm{CH}_{2} \mathrm{Cl}_{2}$ & {$\left[{ }^{13} \mathrm{C}\right] \mathrm{R}$} & 84.9567 & ${ }^{13} \mathrm{CH}_{2} \mathrm{Cl}_{2}$ \\
\hline trans-1,2-Dichloroethene & 95.9534 & $\mathrm{C}_{2} \mathrm{H}_{2} \mathrm{Cl}_{2}$ & {$\left[{ }^{2} \mathrm{H}_{2}\right] R$} & 64.9941 & $\mathrm{C}_{2}^{37} \mathrm{Cl}^{2} \mathrm{H}_{2}$ \\
\hline Hexane & 86.1096 & $\mathrm{C}_{6} \mathrm{H}_{14}$ & $\mathrm{~L}^{2} \mathrm{H}_{14} \mathrm{JR}$ & 100.1974 & $\mathrm{C}_{6}^{2} \mathrm{H}_{14}$ \\
\hline 1,1-Dichloroethane & 63.0001 & $\mathrm{C}_{2} \mathrm{H}_{4} \mathrm{Cl}$ & {$\left[{ }^{2} \mathrm{H}_{3}\right] R$} & 66.0189 & $\mathrm{C}_{2} \mathrm{HCl}^{2} \mathrm{H}_{3}$ \\
\hline cis-1,2-Dichloroethene & 95.9534 & $\mathrm{C}_{2} \mathrm{H}_{2} \mathrm{Cl}_{2}$ & {$\left[{ }^{2} \mathrm{H}_{2}\right] \mathrm{R}$} & 64.9941 & $\mathrm{C}_{2}^{37} \mathrm{Cl}^{2} \mathrm{H}_{2}$ \\
\hline 2-Butanone & 72.0575 & $\mathrm{C}_{4} \mathrm{H}_{8} \mathrm{O}$ & {$\left[4-{ }^{2} \mathrm{H}_{3}\right] R$} & 75.0764 & $\mathrm{C}_{4} \mathrm{H}_{5}^{2} \mathrm{H}_{3} \mathrm{O}$ \\
\hline Chloroform & 82.9455 & $\mathrm{CHCl}_{2}$ & {$\left[{ }^{13} \mathrm{C}\right] \mathrm{R}$} & 83.9489 & ${ }^{13} \mathrm{CHCl}_{2}$ \\
\hline 1,1,1-Trichloroethane & 96.9612 & $\mathrm{C}_{2} \mathrm{H}_{3} \mathrm{Cl}_{2}$ & {$\left[{ }^{2} \mathrm{H}_{3}\right] R$} & 99.9800 & $\mathrm{C}_{2} \mathrm{Cl}_{2}^{2} \mathrm{H}_{3}$ \\
\hline Carbon tetrachloride & 116.9066 & $\mathrm{CCl}_{3}$ & {$\left[{ }^{13} \mathrm{C}\right] \mathrm{R}$} & 117.9099 & ${ }^{13} \mathrm{CCl}_{3}$ \\
\hline Benzene & 78.0470 & $\mathrm{C}_{6} \mathrm{H}_{6}$ & {$\left[{ }^{13} \mathrm{C}_{6}\right] \mathrm{R}$} & 84.0671 & ${ }^{13} \mathrm{C}_{6} \mathrm{H}_{6}$ \\
\hline 1,2-Dichloroethane & 61.9923 & $\mathrm{C}_{2} \mathrm{H}_{3} \mathrm{Cl}$ & {$\left[{ }^{2} \mathrm{H}_{4}\right] R$} & 67.0169 & \\
\hline Trichloroethene & 129.9144 & $\mathrm{C}_{2} \mathrm{HCl}_{3}$ & {$\left[{ }^{13} \mathrm{C}\right] \mathrm{R}$} & 130.9177 & ${ }^{13} \mathrm{CCHCl}_{3}$ \\
\hline 1,2-Dichloropropane & 63.0002 & $\mathrm{C}_{2} \mathrm{H}_{4} \mathrm{Cl}$ & {$\left[{ }^{2} \mathrm{H}_{6}\right] \mathrm{R}$} & 67.0253 & $\mathrm{C}_{2} \mathrm{Cl}^{2} \mathrm{H}_{4}$ \\
\hline Dibromomethane & 171.8523 & $\mathrm{CH}_{2}^{79} \mathrm{Br}_{2}$ & {$\left[{ }^{2} \mathrm{H}_{2}\right] \mathrm{R}$} & 177.8608 & $\mathrm{C}^{7} \mathrm{H}_{2}^{81} \mathrm{Br}_{2}$ \\
\hline Bromodichloromethane & 82.9455 & $\mathrm{CHCl}_{2}$ & {$\left[{ }^{13} \mathrm{C}\right] \mathrm{R}$} & 83.9489 & ${ }^{13} \mathrm{CHCl}_{2}$ \\
\hline Toluene & 91.0548 & $\mathrm{C}_{7} \mathrm{H}_{7}$ & {$\left[{ }^{2} \mathbf{H}_{8}\right] \mathrm{R}$} & 98.0987 & $\mathrm{C}_{7}^{2} \mathrm{H}_{7}$ \\
\hline 1,1,2-Trichloroethane & 96.9612 & $\mathrm{C}_{2} \mathrm{H}_{3} \mathrm{Cl}_{2}$ & {$\left[{ }^{2} \mathrm{H}_{3}\right] R$} & 99.9800 & $\mathrm{C}_{2} \mathrm{Cl}_{2}^{2} \mathrm{H}_{3}$ \\
\hline Tetrachloroethene & 165.8725 & $\mathrm{C}_{2}^{37} \mathrm{ClCl}_{3}$ & {$\left[{ }^{13} \mathrm{C}\right] \mathrm{R}$} & 166.8758 & ${ }^{13} \mathrm{CC}^{37} \mathrm{ClCl}_{3}$ \\
\hline Dibromochloromethane & 128.8923 & c & {$\left[{ }^{13} \mathrm{C}\right] \mathrm{R}$} & 129.8958 & d \\
\hline Chlorobenzene & 112.0080 & $\mathrm{C}_{6} \mathrm{H}_{5} \mathrm{Cl}$ & $\left.I^{2} \mathrm{H}_{5}\right] \mathrm{R}$ & 117.0394 & $\mathrm{C}_{6} \mathrm{Cl}^{2} \mathrm{H}_{5}$ \\
\hline Ethylbenzene & 106.0783 & $\mathrm{C}_{\mathrm{a}} \mathrm{H}_{10}$ & {$\left[{ }^{2} \mathrm{H}_{10}\right] \mathrm{R}$} & 116.1410 & $\mathrm{C}_{8}^{2} \mathrm{H}_{10}$ \\
\hline$m-/ p-X y l e n e$ & 106.0783 & $\mathrm{C}_{8} \mathrm{H}_{10}$ & {$\left[{ }^{2} \mathrm{H}_{10}\right] p-\mathrm{R}$} & 116.1410 & $\mathrm{C}_{8}^{2} \mathrm{H}_{10}$ \\
\hline$a-X y l e n e$ & 106.0783 & $\mathrm{C}_{8} \mathrm{H}_{10}$ & {$\left[{ }^{13} \mathrm{C}_{2}\right] \mathrm{R}$} & 108.0850 & ${ }^{13} \mathrm{C}_{2} \mathrm{C}_{6} \mathrm{H}_{10}$ \\
\hline Styrene & 104.0626 & $\mathrm{C}_{8} \mathrm{H}_{8}$ & {$\left[{ }^{2} \mathrm{H}_{8}\right] R$} & 112.1128 & $\mathrm{C}_{8}^{2} \mathrm{H}_{8}$ \\
\hline Bromoform & 172.8425 & $\mathrm{CH}^{79} \mathrm{Br}^{81} \mathrm{Br}$ & {$\left[{ }^{13} \mathrm{C}\right] \mathrm{R}$} & 173.8458 & ${ }^{13} \mathrm{CH}^{79} \mathrm{Br}^{81} \mathrm{~B}$ \\
\hline 1,1,2,2-Tetrachloroethane & 82.9455 & $\mathrm{CHCl}_{2}$ & $\left.\mathrm{I}^{2} \mathrm{H}_{2}\right] \mathrm{R}$ & 83.9518 & $\mathrm{CCl}_{2}^{2} \mathrm{H}$ \\
\hline 1,3-Dichlorobenzene & 145.9690 & $\mathrm{C}_{6} \mathrm{H}_{4} \mathrm{Cl}_{2}$ & $\theta$ & & \\
\hline 1,4-Dichlorobenzene & 145.9690 & $\mathrm{C}_{6} \mathrm{H}_{4} \mathrm{Cl}_{2}$ & {$\left[{ }^{2} \mathrm{H}_{4}\right] \mathrm{R}$} & 151.9912 & $\mathrm{C}_{6}^{37} \mathrm{ClCl}^{2} \mathrm{H}_{4}$ \\
\hline 1,2-Dichlorobenzene & 145.9690 & $\mathrm{C}_{6} \mathrm{H}_{4} \mathrm{Cl}_{2}$ & {$\left[{ }^{2} \mathrm{H}_{4}\right] \mathrm{R}$} & 151.9912 & $\mathrm{C}_{6}^{37} \mathrm{ClCl}^{2} \mathrm{H}_{4}$ \\
\hline Hexachloroethane & 165.8725 & $\mathrm{C}_{2}^{37} \mathrm{ClCl}_{3}$ & {$\left[{ }^{13} \mathrm{C}\right] \mathrm{R}$} & 166.8758 & ${ }^{13} \mathrm{CC}^{37} \mathrm{ClCl}_{3}$ \\
\hline
\end{tabular}

ions at nominal mass $(98,100,61$, and $63 \mathrm{Da})$ cannot be separated by using enhanced resolution. The only unique ions with enough intensity to be useful are $\mathrm{C}_{2} \mathrm{H}_{2}^{35} \mathrm{Cl}_{2}^{+}$at $m / z 95.9534$ for 1,1-dichloroethene and $\mathrm{C}_{2}^{2} \mathrm{H}_{2}^{37} \mathrm{Cl}^{+}$at $m / z$ 64.9941 for $\left[{ }^{2} \mathrm{H}_{2}\right]-1,1$-dichloroethene, the intensities of which are, respectively, 80 and $30 \%$ of their base peaks. Similar problems with coelution and common ions determine the choice of the quantitation ions for the cis-1,2-dichloroethene, trans-1,2-dichloroethene, 1,4-dichlorobenzene, 1,2-dichlorobenzene, and their deuterated analogs. On the DB-624 column, $o$-xylene and styrene elute within 3 sec of each other and pose another common ion problem. The loss of two hydrogens from o-xylene's molecular ion, $\mathrm{C}_{8} \mathrm{H}_{10}^{+}$, produces a low-intensity ion with the same molecular formula as the molecular ion of styrene, $\mathrm{C}_{8} \mathrm{H}_{8}^{+}$, which is the base peak for styrene. Even styrene's next most intense ion $\mathrm{C}_{8} \mathrm{H}_{7}^{+}$is common to $o$-xylene. To achieve the greatest sensitivity for styrene, one must use its molecular ion for the quantitation ion and correct for the contribution of any 0 xylene. The use of carbon-13-labeled internal standards produces coeluting GC peaks for each native analyte and its carbon-13-labeled analog. Therefore, the natu- 
ral abundance of carbon- 13 in the ions of native VOCs must be taken into account when the single-ion chromatograms are analyzed. The use of multilabeled carbon-13 analogs can help minimize this interference.

For quantitation one must correct for the contribution of the labeled analog to the quantitation mass of the analyte and vice versa using native and label mass ratios that are independently determined by experiment. The native mass ratio, $R_{x}$, is determined from a concentrated water standard solution without any internal standard. $R_{\mathrm{x}}$ is calculated by dividing the area of the analyte quantitation ion signal at the analyte retention time by the area of the analyte contribution to the analng quantitation ion at the analyte retention time. The label mass ratio, $R_{y}$, is determined from a blank water sample containing a high concentration of the internal standard. $R_{y}$ is calculated by dividing the area of the analog contribution to the analyte quantitation ion signal at the analog retention time by the area of the analog quantitation ion signal at the analog retention time. For a standard or unknown sample, the analyte-to-analog ratio, $R_{\mathrm{m}}$, is determined by dividing the area of the analyte quantitation ion signal at the analyte retention time by the area of the analog quantitation ion signal at the analog retention time. The relative response factor, $R R$, for an analyte is calculated using the equation

$$
\mathrm{RR}=\left(R_{\mathrm{y}}-R_{\mathrm{m}}\right)\left(R_{\mathrm{x}}+1\right) /\left(R_{\mathrm{m}}-R_{\mathrm{x}}\right)\left(R_{\mathrm{y}}+1\right)
$$

For computational purposes, $R_{\mathrm{x}}$ equals $10^{7}$ when there is no analyte contribution to the analog quantitation ion signal, and $R_{\mathrm{y}}$ equals $10^{-6}$ when there is no analog contribution to the analyte quantitation ion. For each analyte, a calibration curve in standard water solutions was made by using a five-point curve of standard concentration versus $\mathrm{RR} /$ (sample weight). In each case the curve was linear over the range of expected results, and its slope was used in calculating the unknown concentration, $C$, by the equation

$C=(R R) /($ slope of calibration curve)(sample weight)

The detection limit of each analyte was determined from a plot of the standard deviation of the calculated concentration versus the known standard concentration, using established procedures [26, 27]. The $y$ intercept, $S_{0}$, of the best least squares linear fit is determined; this is the standard deviation at zero concentration. The detection limit is 3 times $S_{0}$ and the quantitation limit for reporting results is 7 times $S_{0}$.

\section{Comparison of Nominal and Accurate Mass Data for Quantitation}

The use of a magnetic sector mass spectrometer at even the medium resolving power of 3000 has signifi- cant advantages over the nominal (integer) mass resolving power of a quadrupole mass spectrometer. Previous work using quadrupole instruments achieved detection limits for VOCs in human blood in the parts per billion to high parts per trillion range. Our method using a magnetic sector mass spectrometer has achieved detection limits in the low parts per trillion range for most target VOCs in a $10-\mathrm{mL}$ sample of whole blood. The use of higher mass resolution to eliminate interferences from coeluting compounds (seen at nominal mass resolution) can be demonstrated for methylene chloride, chloroform, and $\left[{ }^{13} \mathrm{C}_{3}\right.$ lacetone in Figures 1, 2, and 3, respectively, for a 9.59-g sample of whole human blood from the NHANES III study. For this blood sample, the concentrations of chloroform and $\left[{ }^{13} \mathrm{C}_{3}\right]$ acetone were $110 \mathrm{ppt}$ and $10 \mathrm{ppb}$, respectively; the level of methylene chloride is at the background level of 80 ppt present in the vacutainer itself. In Figures 1, 2, and 3 the accurate mass chromatograms at 3000 resolution were constructed from the full-scan data using the appropriate accurate mass of the quantitation ion with a limited mass window of $0.03 \mathrm{Da}$; and the nominal (integer) mass chro matograms were constructed from the full scan data using the appropriate integral mass of the quantitation ion with the default unit mass window. The quantitation ions of methylene chloride $\left(\mathrm{CH}_{2}^{35} \mathrm{Cl}_{2}^{+*}, \mathrm{~m} / \mathrm{z}\right.$ 83.9534), chloroform $\left(\mathrm{CH}^{35} \mathrm{Cl}_{2}^{+}, m / z\right.$ 82.9455), and $I^{13} \mathrm{C}_{3}$ lacetone $\left({ }^{13} \mathrm{C}_{3} \mathrm{H}_{6} \mathrm{O}^{+} ; m / z\right.$ 61.0519) are fully resolved at 3000 resolution from other coeluting ions with the same nominal (integer) mass. The coeluting ions interfering at nominal mass resolution with methylene chloride, chloroform, and $\left[{ }^{13} \mathrm{C}_{3}\right]$ acetone are, respectively, $\mathrm{C}_{6} \mathrm{H}_{12}^{+\cdot}(m / z 84.0939), \mathrm{C}_{6} \mathrm{H}_{11}^{+}(\mathrm{m} / z$ 83.0861), and $\mathrm{C}_{2} \mathrm{H}_{5} \mathrm{~S}^{\prime}(\mathrm{m} / \mathrm{z}$ 61.0112). In fact less than 3000

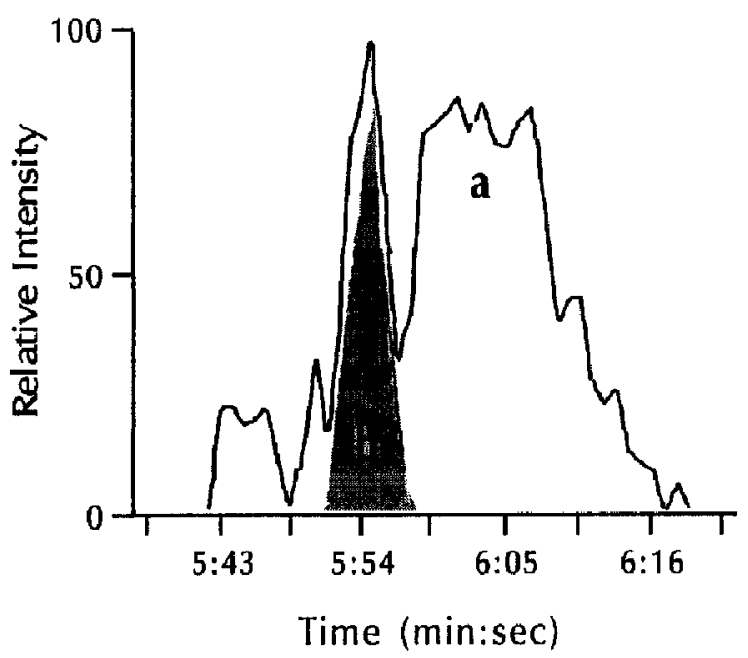

Figure 1. Single-mass chromatograms for methylene chloride from a blood sample $(9.59 \mathrm{~g})$ : (a) nominal mass curve for $m / z 84$; (b) accurate mass curve for $\mathrm{CH}_{2} \mathrm{Cl}_{2}^{+}(m / z 83.953$ with a window of 0.03 ). 


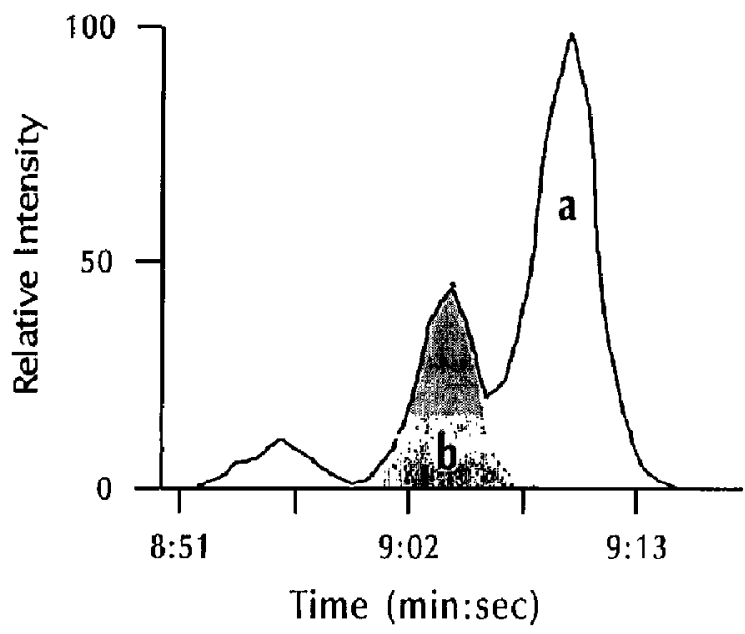

Figure 2. Single-mass chromatograms for chloroform from a blood sample ( $9.59 \mathrm{~g}$ ): (a) nominal mass curve for $m / z 83$; (b) accurate mass curve for $\mathrm{CHCl}_{2}^{+}(\mathrm{m} / z 82.945$ with a window of $0.03)$.

resolution would be required to separate these analytes' quantitation ions from their interfering ions: 600 resolution for methylene chloride and chloroform; 1500 resolution for $\left[{ }^{13} \mathrm{C}_{3}\right]$ lacetone. The point of these figures is that accurate quantitation for these VOCs in blood at low parts per trillion levels is not possible with the nominal (integer) mass resoultion of a quadrupole mass spectrometer. In various blood samples we have examined, the relative amounts of the interfering ions vary greatly from sample to sample from the relatively low levels seen in Figures 1, 2, and 3 from this particular blood sample to levels up to 5 to 10 times higher such that the signals for the quantitation ions are

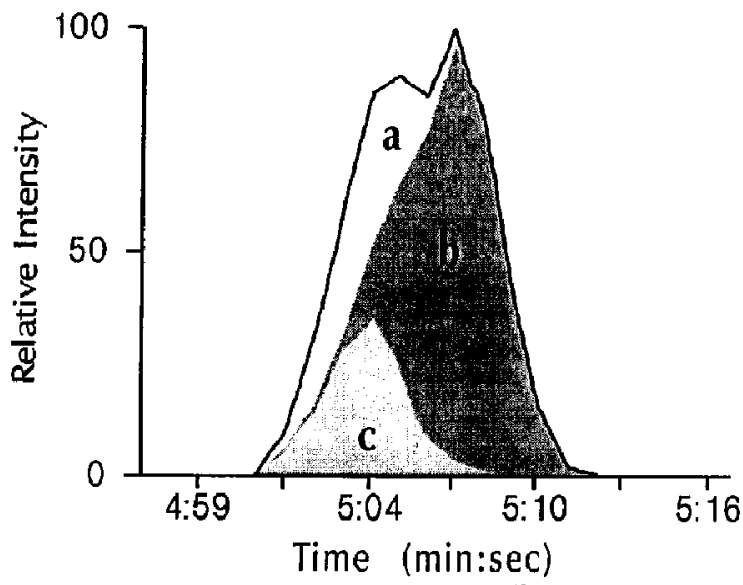

Figure 3. Single-mass chromatograms for $\left[{ }^{13} C_{3}\right]$ acetone from a blood sample (9.59 g): (a) nominal mass curve for $m / z$ 61; (b) accurate mass curve for $\left({ }^{13} \mathrm{CH}_{3}\right)_{2}^{13} \mathrm{CO}^{+\cdot}(m / z$ 61.052 with a window of 0.03): (c) accurate mass curve for $\mathrm{C}_{2} \mathrm{H}_{5} \mathrm{~S}^{+}(\mathrm{m} / z$ 61.011 with a window of 0.03 ). completely masked in the nominal (integer) mass chromatogram by the interfering ions.

The advantage of accurate mass data (at 3000 resolution) over nominal (integer) mass data can be demonstrated for the quantitation of six analytes, which, at nominal (integer) mass, involve significant interferences in blood and serum. Using nominal (integer) mass data, the rative mass ratio, $R_{x}$ and label mass ratio, $R_{y}$, of each analyte are the following (analyte $\left(R_{x}, R_{y}\right)$ ): chloroform $(29.17,0.1671)$, acetone $\left(10^{7}\right.$, $0.005970)$, methylene chloride $(34.43,0.1002), 1,1.2$-trichloroethane $\left(15.58,10^{-6}\right), 1,1,2,2$-tetrachloroethane (35.41, 0.09271), trans-1,2-dichloroethene $(60.25,0.1544)$. Using accurate mass data, these ratios are the following (analyte $\left(R_{x}, R_{y}\right)$ ): chloroform $29.38,0.08864$ ), acetone $(761.7,0.004151)$, methylene chloride (33.55, $0.08873), 1,1,2$-trichloroethane $\left(27.06,10^{-6}\right), 1,1,2,2-$ tetrachloroethane $(35.03,0.04799)$, trans-1,2-dichloroethene $\left(10^{7}, 10^{-6}\right)$. Using these mass ratios, standard calibration curves can be prepared for these six analytes in water by using a five-point curve of standard concentration versus relative response factor divided by sample wcight. Table 4 summarizes the standard calibration curves of these analytes in water; the curves are linear over their expected ranges in blood and serum (analyte, concentration range): (chloroform, 10-2000 ppt), (acetone, 100-3000 ppb), (methylene chloride, 10-800 ppt), (1,1,2-trichloroethane, 10-1500 ppt), (1,1,2,2-tetrachloroethane, 10-1000 ppl), (trans1,2-dichloroethene, $10-2000 \mathrm{ppt}$ ). The small slope value 0.00021 for acetone results from its great water solubility which produces a low recovery of the acetone from water by helium purging. Significant interference from coeluting compounds even in standard water solutions was found as reflected by the size of the difference in slope between nominal (integer) and accurate mass calibration curves (analyte, slope difference): (1,1,2-trichloroethane, 0.454), (trans-1,2-dichloroethene, 0.104), (chloroform, 0.095), (1,1,2,2-tetrachloroethane, -0.044). This interference comes from the background levels of interfering ions from both the water and the purge and trap apparatus.

The effect of nominal (integer) and accurate mass data on the quantitation of these six analytes in blood and in the quality control serum are summarized in Table 5 for six samples of blood and six samples each of two levels of spiked quality control serum (QC-high and QC-mid). For each six-sample set Table 5 shows for each analyte the mean concentration difference in parts per billion between pairs of accurate $A_{i}$ and nominal $N_{i}$ mass data: $n^{-1} \sum\left(A_{i}-N_{i}\right)$, where $n$ is the number of pairs. A paired-comparison $t$-test was run on the corresponding sets of accurate and nominal mass data to determine if the difference in concentration was statistically different from zero. The difference between two sets of measurements is not significantly different from zero if the probability of the paired $t$-distribution has a value greater than 0.05 , which was found to be the case for only 1,1,2,2-tetra- 
Table 4. Linear calibration curves in standard water solutions

\begin{tabular}{|c|c|c|c|c|}
\hline \multirow[b]{2}{*}{ Target VOCs } & \multicolumn{2}{|c|}{ Nominal mass data } & \multicolumn{2}{|c|}{ Accurate mass data ${ }^{\theta}$} \\
\hline & Intercept & $\begin{array}{l}\text { Slope } \pm \\
\text { standard error }\end{array}$ & Intercept & $\begin{array}{l}\text { Slope } \pm \\
\text { standard error }\end{array}$ \\
\hline 1,1,2,2-Tetrachloroethane & -0.0128 & $0.7799 \pm 0.0279$ & -0.0105 & $0.8241 \pm 0.0312$ \\
\hline 1,1,2-Trichloroethane & -0.0075 & $1.6316 \pm 0.1139$ & -0.0177 & $1.1779 \pm 0.0164$ \\
\hline Acetone & -0.0013 & $0.00021 \pm 0.00001$ & 0.0012 & $0.00021 \pm 0.00001$ \\
\hline Chloroform & 0.0501 & $0.9216 \pm 0.0433$ & 0.0482 & $1.0169 \pm 0.0416$ \\
\hline methylene chloride & 0.0121 & $0.1797 \pm 0.0033$ & 0.0125 & $0.1834 \pm 0.0032$ \\
\hline trans-1,2-Dichloroethene & -0.0104 & $1.3636 \pm 0.0342$ & 0.0242 & $1.2592 \pm 0.0310$ \\
\hline
\end{tabular}

Accurate value used for the quantitation ians is the theoretical mass-to-charge ratio with a window of 0.03 .

chloroethane in serum. The mean pair difference was statistically different from zero in the other cases of the measured analytes in Table 5 . Both the magnitudes of the mean pair difference and the corresponding standard error in this mean determine the value of the paired t-test: the smaller the mean pair difference and the larger the corresponding standard error relative to the mean pair difference, the larger the value of the paired $t$-test. The mean pair difference is effectively zero for 1,1,2,2-tetrachloroethane in the sets of quality control serum because the interfering compounds have been effectively eliminated by the helium purging performed before spiking; the value of the paired $t$-test is greater than 0.1 in the serum, which indicates that the mean pair difference is statistically zero.

In Table 5, the magnitude of the relative error in the calculated concentration incurred by using nominal mass data is indicated by the mean relative percent difference: $100 n^{-1} \Sigma\left[\left(A_{i}-N_{i}\right) / A_{i}\right]$. The levels of interfering compounds in whole blood were much higher than those in the specially prepared quality control serum. In the six blood samples, the following analytes were below the detection limit (analyte (detection limit in $\mathrm{ppb})$ ): 1,1,2,2-tetrachloroethane (0.031), trans-1,2dichloroethene (0.024), and 1,1,2-trichloroethane (0.027); these analytes are not normally found in blood.

Table 5. Comparison of accurate and nominal mass data for quantitation of VOCs in blood and quality control serum (QC-high and QC-mid)

\begin{tabular}{|c|c|c|c|c|}
\hline \multirow[b]{2}{*}{ Target VOCs } & \multirow[b]{2}{*}{ Sample $(n)$} & \multicolumn{2}{|c|}{$\begin{array}{l}\text { Mean concentration difference of } \\
\text { accurate } \mathcal{A}_{i} \& \text { nominal } N_{i} \text { pairs }\end{array}$} & \multirow[b]{2}{*}{$\begin{array}{l}\text { Paired } t \text {-test } \\
\text { prob }>|t|\end{array}$} \\
\hline & & $\begin{array}{l}n^{-1} \Sigma\left(A_{i}-N_{i}\right) \\
\pm \text { std error }(p p b)\end{array}$ & $\begin{array}{l}\text { Mean relative } \\
\text { difference }(\%)^{\mathrm{a}}\end{array}$ & \\
\hline \multirow[t]{3}{*}{$1,1,2,2$-Tetrachloroethane } & Blood (6) & $-0.2178 \pm 0.0437$ & $\bar{b}$ & 0.0042 \\
\hline & QC-high (6) & $-0.0082+0.0042$ & -3.52 & 0.104 \\
\hline & OC-mid $(6)$ & $-0.0019 \pm 0.0011$ & -1.61 & 0.148 \\
\hline \multirow[t]{3}{*}{ 1,1,2-Trichloroethane } & Blood (6) & $-0.0658 \pm 0.0068$ & b & 0.0002 \\
\hline & OC-high (6) & $0.0297 \pm 0.0102$ & 10.25 & 0.0333 \\
\hline & OC-mid $(6)$ & $0.0274 \pm 0.0067$ & 17.00 & 0.0098 \\
\hline \multirow[t]{3}{*}{ Acetone } & Blood (6) & $2130 \pm 1476$ & 38.95 & $c$ \\
\hline & OC-high (6) & $7.4469 \pm 0.8432$ & 0.89 & 0.0003 \\
\hline & QC-mid (6) & $10.6853 \pm 1.6487$ & 1.31 & 0.0013 \\
\hline \multirow[t]{2}{*}{ Chloroform } & OC-high (6) & $-0.1576 \pm 0.0207$ & -5.43 & 0.0006 \\
\hline & OC-mid (6) & $-0.0635 \pm 0.0071$ & -3.65 & 0.0003 \\
\hline \multirow[t]{3}{*}{ Methylene chloride } & Blood (6) & $-0.0235 \pm 0.0063$ & -26.52 & 0.0137 \\
\hline & oc-high (6) & $0.0127 \pm 0.0026$ & 0.19 & 0.0047 \\
\hline & QC-mid (6) & $-0.0069 \pm 0.0023$ & -0.22 & 0.0276 \\
\hline \multirow[t]{2}{*}{ trans-1,2-Dichloroethene } & oC-high (6) & $0.0943 \pm 0.0106$ & 15.02 & 0.0003 \\
\hline & QC-mid (6) & $0.0462 \pm 0.0018$ & 21.13 & 0.0001 \\
\hline
\end{tabular}

a The mean relative percent difference is $100 n^{-1} \Sigma\left[\left(A_{i}-N_{i}\right) / A_{i}\right]$.

b The analyte is below the detection limit in the blood samples; the signal seen at nominal mass is all from the interfering ion.

${ }^{6}$ The amount of the interfering ion $\mathrm{C}_{2} \mathrm{H}_{5} \mathrm{~S}^{+}$varied by a factor of 10 among the six blood samples; this produced such a wide range $(17-68 \%)$ of decrease in calculated acetone concentration for nominal mass data that the paired $t$-test for acetone in blood was not significant. 
The detection limits in blood for acetone, chloroform, and methylene chloride are, respectively, 11, 0.040, and $0.080 \mathrm{ppb}$. At nominal mass, however, significant signals from other coeluting compounds from blood were found for the quantitation ions of 1,1,2,2-tetrachloroethane $\left(\mathrm{CH}^{35} \mathrm{Cl}_{2}^{+}, m / z\right.$ 82.9455) and 1,1,2-trichloroethane $\left(\mathrm{C}_{2} \mathrm{H}_{3}^{35} \mathrm{Cl}_{2}^{+}, m / z\right.$ 96.9612) with the interfering ions $\mathrm{C}_{6} \mathrm{H}_{11}^{+}\left(\mathrm{m} / z\right.$ 83.0861) and $\mathrm{C}_{7} \mathbf{H}_{13}^{+}(\mathrm{m} / z$ 97.1017), respectively. In this case, the nominal mass data produced completely erroneous results for the blood samples because the signals at nominal mass are all from the interfering ions but the signals at accurate mass are just the background noise. For trans-1,2-dichloroethene, no ion is present in the blood or serum to interfere with its quantitation ion; the interference occurs only for its labeled analog's quantitation ion $\left(\mathrm{C}_{2}^{2} \mathrm{H}_{2}^{37} \mathrm{Cl}^{+} ; m / z\right.$ 64.9941) with the interfering ion $\mathrm{C}_{5} \mathrm{H}_{5}^{+}(\mathrm{m} / z$ 65.0391); this results in significant errors in the calculated concentration if nominal mass data are used (about 15 and $21 \%$ less than the actual values in the serums QC-high and QC-mid, respectively). Significant interference in the blood from the ion $\mathrm{C}_{6} \mathrm{H}_{12}^{+}$. ( $m / z$ 84.0939) occurred at nominal mass for methylene chloride's quantitation ion $\mathrm{CH}_{2}^{35} \mathrm{Cl}_{2}^{+\cdot}(m / z$ 83.9534), resulting in a concentration value about $27 \%$ greater than the actual value if nominal mass data are used. For the six blood samples examined here, the signal for chloroform's quantitation ion $\mathrm{CH}^{35} \mathrm{Cl}_{2}^{+}(m / z$ 82.9455) at nominal mass was only a shoulder on an intense interfering signal from the ion $\mathrm{C}_{6} \mathrm{H}_{11}^{1}(\mathrm{~m} / z$ 83.0861); as a result, no meaningful area estimation could be made.

For acetone in blood, the coeluting ion $\mathrm{C}_{2} \mathrm{II}_{5} \mathrm{~S}^{+}$ $(m / z$ 61.0112) interfered with the quantitation ion of the labeled analog ${ }^{13} \mathrm{C}_{3} \mathrm{H}_{6} \mathrm{O}^{+\cdot}(\mathrm{m} / z$ 61.0519). For the six blood samples, the amount of this interfering ion varied by a factor of 10 . For nominal mass data, this interference produced an apparent decrease in acetone concentration ranging from 17 to $68 \%$ of the true amount determined by using accurate mass data. Since the difference between acetone concentration for accurate and nominal mass data is so large, the paired $t$-test for this analyte in blood was not applicable.

\section{Conclusions}

The use of a magnetic sector mass spectrometer instead of a quadrupole mass spectrometer permits us to use enhanced mass resolution (3000 resolving power) in place of nominal mass resolution to isolate the quantitation ions of target VOCs and their labeled analogs from the ions of coeluting compounds purged from blood and serum by the purge-and-trap analysis. The magnetic sector mass spectrometer is sufficiently stable to permit the generation of accurate mass chromatograms from full scan mass data without the necessity for the simultaneous presence of a calibration compound (PFK) during the data acquisition. These accurate mass data are of sufficient quality to allow the automated generation of mass chromatograms from the theoretical masses with a mass window of $0.03 \mathrm{Da}$ over the entire GC/MS run. The use of isotope dilution mass spectrometry with purge-and-trap analysis and detection by a magnetic sector mass spectrometer operating in full-scan mode at medium resolution permits us to achieve detection limits in the low parts per trillion range for most target VOCs from a $10-\mathrm{mL}$ sample of whole blood. Full-scan data were used in this method instead of selected ion recording so that analytes not on the current target list of the NHANES III survey could be identified in the blood.

\section{Acknowledgments}

This research was funded by the Agency for Toxic Substances and Disease Registry. Use of trade names is for identification only and does not constitute endorsement by the Public Health Service or the Department of Health and Human Services.

\section{References}

1. Molhave, L.; Bach, B.; Pedersen, O. F. Environ. Int. 1986, 12, 167-175.

2. Ott, W.; Wallace, L.; Mage, D.; et al. Environ. Int. 1986, 12, 475-494.

3. Andelman, J. B. Sci. Total Environ. 1985, 47, 443-460.

4. Andelman, J. B.; Meyers, S. M.; Wilder, L. C. In Chemicals in the Environment; Lester, J. N., Perry, R., Sterritt, R. M., Eds.; Selper: London, 1986; pp 323-330.

5. Andelman, J. B.; Meyers, S. M.; Wilder, L. C. Indoor Air Pollution from Volatile Chemicals in Water; Proceedings-4th International Conference on Indoor Air Quality and Climate; Rerlin, August 1987

6. Brown, H. S; Bishop, D. R.; Rowan, C. A. Am. J. Public Health $1984,74,479-484$.

7. McKone, T. E. Environ. Sci. Technol. 1987, 21, 1194-1201.

8. Conner, T. H.; Theiss, J. C.; Hana, H. A.; et al. Toxicol. Lett. $1985,25,33-40$.

9. Nero, A. V. Jr. Sci. Am. 1988, 258, 5, 42-48.

to. Otson, R.; Doyle, E. E.; Williams, D. T.; Bothwell, P. D. Bull. Environ. Contam. Toxicol. 1983, 31, 222-229.

11. Pellizzari, E. D.; Hartwell, T. D., Perritt, R. L.; et al. Environ. Int. 1986, 12, 619-623.

12. Berlin, M. Am. J. Ind. Med. 1985, 7, 365-373.

13. Wallace, L. A.; Pellizzari, E. D.; Hartwell, T. D.; et al. Environ. Int. 1986, 12, 369-387.

14. Wallace, L. A.; Pellizzari, E. D.; Hartwell, T. D.; et al. Environ. Res. 1987, 43, 290-307.

15. Angerer, J. Scand. J. Work. Environ. Health 1985, 11 (suppl 1), $45-52$.

16. Brugnone, F,; De Rosa, E.; Perbellini, L.; Bartolucci, G. B. Br. J. Ind. Med. 1986, 43, 56-61.

17. Rrugnone, F: Perbellini, I.; Faccini, G. B.; et al. Int. Arch. Occup. Environ. Health 1989, 61, 303-311.

18. Antoine, S. R; DeLeon, I. R.; O'Dell-Smith, R. M. Bull. Environ. Contam. Toxicol. 1986, 36, 364-371.

19. Cocheo, V.; Silvestri, R.; Bombi, G. G.; Perbellini, L. Am. Ind. Hyg. Assoc. J. 1982, 43, 938-941.

20. National Center for Health Statistics. Plan and operation of NHANES I (1971-1974); Vital and Health Statistics Series 1, DHEW Pub. No. (PHS) 79-1310; National Center for Health Statistics: Rockville, MD, 1977.

21. National Center for Health Statistics. Plan and operation of NHANES II (1976-1980); Vital and Health Statistics Series 1, 
DHEW Pub. (PHS) 81-1317; National Center for Health Statistics: Hyattsville, MD, 1981.

22. National Center for Health Statistics. Dutu from the Nalional Health Examination Survey and the National Health and Nutrition Examination Surdey; Vital and Health Statistics Series 11; National Center for Health Statistirs: Hyattsville, MD.

23. Ashley, D. L.; Bonin, M .B.; Cardinali, F. L.; McCraw, J. M.; Holler, J. S.; Needham, L. L.; Patterson, D. G. Anal. Chem. 1992, 64, 1021-1029.
24. Michael, L. C.; Pellizzari, E. D.; Wiseman, R. W. Environ. Sci. Technol. 1988, 22, 565-570.

25. Colby, B. N.; McCaaman, M. W. Biomed. Mass Spectrom. 1979, $6,225-230$.

26. Taylor, J. K. Quality Assurance of Chemical Measurements; Lewis Publishers: Chelsea, Michigan, 1987; pp 75-85.

27. American Chemical Society Committee Report, "Principles of Environmental Measurement," Anal. Chem. 1983, 55, 2210-2218. 